\title{
SUGGESTIONS CONCERNING AN INTERNATIONAL CODE ON THE LAW OF NATIONALITY
}

\author{
RichaRD W. FLOURNOY, JR.
}

The subject of the conflicts of nationality laws has already been discussed at some length by the writer in articles published in the YALE LAW JOURNAL. ${ }^{1}$ Since those articles were published, this whole subject has received the attention of several organizations devoted to the study of international law problems and of the League of Nations, and the possibility of having these conflicts settled through international agreements of some kind seems less remote than it did a few years ago. In a meeting at Lima, Peru, in December 1924, the American Institute of International Lav: adopted a proposed Pan-American Convention on the subject of nationality. This project was discussed at the meetings of the American Society of International Law at Washington in April, 1925. and 1926. The general question was also discussed rather fully at the meeting of the International Law Association at Stockholm, September $S$ to 13,1924 , and resolutions were adopted recommending the adoption of an international code, in the form of a model statute and multilateral convention. ${ }^{3}$ Last year the subject was taken up by the committee of the League of Nations on codification of international law, and the sub-committee on nationality laws reported in January last. This report has just been made public."

In this article the writer will consider the subject with reference to the measures now being attempted for having conflicts of nationality laws settled by international agreements. Before attempting to make suggestions concerning a model statute to be recommended for adoption by all countries, or a multilateral treaty for the termination of conflicts of nationality laws, or both, it seems necessary to consider certain underlying prineiples or concepts, and in order to do this it is necessary to direct attention first to the conditions which give rise to the conflicts.

1 Dual Nationality and Election (1921) 30 YaLe LAW JounNar, 515, 698; Naturalization and Expatriation (1922) 31 YARE LAW JoxnNa, 702, 845; The New Married Women's Citizenship Law (1923) 33 Yase Law JoerNAL, 159.

2 Proceedings of the American Socicty of Intcmational Lau", Washington, D. C., April 23-25, 1925.

Interiational Lav Association Reports, Thirty-third Conference (1024) 22.

4 Publications of the League of Nations (1926) V. Legal, V.1. (Committee of Experts for the Progressive Codification of International Law: Report on Nationality). 
If we had to do solely with the status of true emigrants, that is, persons who migrate from one country and settle permanently in another, taking with them their wives and children if they are married, the problem would not be so great. The original settlers of our country were mostly of the class just mentioned. They emigrated with the intention of making a new home in the new land and of remaining there. Political and religious, as well as economic, reasons caused them to seek a new country for their habitation. In recent years the great migrations to the United States, especially from countries of southern and eastern Europe have been due almost entirely to economic causes. The lure of high wages, rather than a desire to find conditions more congenial from the political or religious viewpoint, was the principal cause of the vast influx of aliens into the United States in the period following the Civil War. In other words, great masses of aliens came to the United States for what they could get out of it, and, after they had accumulated enough money, went back to the countries from which they had come to spend the remainder of their lives there. Among these, many, for one reason or another, had obtained naturalization as citizens of the United States. Some, especially Italians, Greeks and Syrians, had left wives in their native lands when they went to the United States; others, especially Czechs and Hungarians, had brought their wives with them and children had been born to them in the United States. These children in many cases were taken by their mothers to the old country and there continued to reside, thinking or caring little or nothing about the country of their birth until they were in danger of being called for military service in the country of their residence or themselves felt the lure of high wages in the United States. It is this shifting population which has given rise to the bulk of the cases involving conflicts of laws.

In the present article it will not be attempted to discuss all of the subjects relating to nationality which may be comprehended in an international code. The particular problems to which attention will be directed in this discussion are (1) the problem of naturalization, including the question of the right of expatriation and the status of naturalized citizens who return to their native lands to reside; (2) the problem of dual nationality; (3) the problem of no nationality or statelessness; and (4) the problem of the status of women married to men having nationalities different from theirs.

Let us now consider briefly certain principles which, it is believed should be recognized as underlying the law of nationality. These principles may be expressed as follows:

1. Nationality involves reciprocal obligations on the part of the state and of the individual.

2. The right of expatriation, as a natural human right, is recog- 
nized. Any limitations thereon must be based upon present, not future, obligations to the state.

3. Nationality should be single and undivided.

4. It is desirable that, so far as possible, members of the same family be of the same nationality.

5. It is desirable that so far as possible, nationality and domicile coincide.

The modern democratic state may be regarded as a people organized for the mutual benefit of its members, and each member may be regarded as voluntarily adhering to the organization. It is true that the great majority of the members of any state have acquired their membership by birth within its territory or by descent, but those who, having reached the age of majority, have remained in the state, may be regarded as having voluntarily adhered to it, and, in doing so, as having voluntarily assumed the obligations of citizenship. Among these obligations are the duty to support the government through payment of taxes, the duty to take part in carrying on government through voting or holding office, the duty to aid the administration of justice by serving on juries when summoned, the duty to aid in the defense of the state when needed, and, in general, the duty to play one's part in the common life, and contribute in some way to the national welfare. In return for the performance of these duties the citizen relies upon the state to grant him protection of person and property at home and abroad and to perform functions of a public charaeter for the advancement of his interests and the interests of the other members of the state. However much the theory of the social contract may be criticised, it remains true that the tie between the member of a modern democratic state and the state itself is in the nature of a contract. Moral allegiance, or loyalty, should, no doubt, in a right-minded person accompany legal allegiance, but it is distinct from it. It is a state of mind, a sense of human obligation or brotherhood, which exists in any association of men banded together for mutual benefit, whether for business, social or religious purposes, and is naturally strongest in the greatest of all associations, the state. In its highest manifestations it is a most noble and generous trait, having a sort of mystic quality; in its lowest it is nothing more than the herd instinet. While loyalty should accompany nationality, it should not be regarded as preventing the individual from separating himself from the state if and when he finds it to his advantage to do so, and transferring his allegiance to another state, for surely the state is made for man and not man for the state. This brings us to the second principle mentioned above.

The history of the "right of expatriation" as advocated by our own country was traced by the present writer in his article in 
this journal on Naturalization and Expatriation." It is hard to conceive of a country such as ours, whose population is made up so largely of expatriates from other countries, failing to recognize the right of expatriation at least as a moral right, if not as a recognized rule of international law. As we shall see, the International Law Association, in its meeting at Stockholm in 1924, ${ }^{\circ}$ seems to have recognized the right of expatriation as now at least worthy of general acceptance, notwithstanding the refusal of some European countries to give it recognition. It must be admitted, however, that the right of expatriation can not be regarded as absolute and unlimited. It must be regarded as subject to reasonable limitations arising out of the obligation of an individual to aid in the defense of the country to which he belongs. This is a difficult point, which will be considered further on.

The third principle mentioned above, that of singleness of allegiance, is generally recognized as a desideratum, although differences of opinion may exist as to how it is to be made effective in all cases. Recognition of allegiance as an artificial, legal tie, subject, with certain limitations, to severance at the will of the individual does not mean that its obligations, so long as the tie exists, are to be lightly regarded. On the contrary the obligations of a tie which is voluntarily maintained are more binding morally than the obligations of a tie which is maintained by the force of the state, and it is difficult to see how any person can voluntarily maintain a true allegiance to more than one state. Obviously, when an individual is a national of two states which are at war with each other, he cannot maintain a true allegiance to both, and even in time of peace it is impossible for an individual at one time to serve two states whole-heartedly as a citizen should. His allegiance to one or the other will be merely nominal, or else his allegiance to both will be weak and uncertain. Reference is made particularly to dual allegiance existing in the case of a person born in one country of parents having the nationality of another. As explained in the writer's article in this Journal on Dual Allegiance and Election, ${ }^{7}$ it frequently happens that such a person is born a national of one state under jus soli and a national of another under jus sanguinis. Under our own law, dual nationality is not recognized as existing in the case of one who has foresworn his former allegiance and assumed American allegiance through naturalization. Whether it will be possible to arrive at satisfactory international agreements for preventing or terminating dual nationality will be considered later.

The fourth principle mentioned above, that so far as possible members of a family should be of the same nationality, hardly

S Supra note 1.

- International Law Association Reports, Third-third Conference (1924).

7 Supra note 1. 
needs argument. This refers, of course, to parents and minor children and to husbands and wives. As to parents and children, there is, however, no reason why the latter should after reaching majority, cleave to the nationality of their parents. The principal difficulty arises from the married women's citizenship act of 1922, known as the Cable Act, ${ }^{8}$ and the laws of some foreign countries under which husbands and wives may have different nationalities.

The last of the principles mentioned, that it is, as a rule, desirable that nationality and domicile coincide, follows logically from the first and third principles. When a person having the nationality of one country establishes himself permanently in another, unless he in some way represents establishments or interests in the country of his nationality, he will not, as a rule, contribute to the welfare of that country as a citizen should. On the contrayy he is apt to transfer his sympathies to the country in which he has established his permanent home or else to lose all sense of national attachment. This is especially true in the case of a naturalized citizen who returns to his country of origin to reside. This does not mean that it is believed that a penalty of any hind should be placed on foreign residence, $p e r$ se, even though it is prolonged. Even permanent residence in a foreign country may be consonant with the retention of nationality when there are special reasons for such foreign residence, other than a mere preference for living in the foreign country. Thus prolonged, and even permanent, foreign residence may be justified by reason of health or the pursuit of art or special studies for which facilities cannot be found in the country of nationality. From the standpoint of the country of domicile, it is undesirable and even perilous to have permanently established within its territory large numbers of persons who do not owe to that country permanent allegiance. Political detachment and irresponsibility are apt to be accompanied by disregard for law and order.

\section{THE PROBLEM OF NATURALIZATION}

The problem of naturalization in its international phase involves questions of the right of expatriation, the liability of naturalized citizens for offenses committed against their countries of origin and the status of naturalized citizens who return to their countries of origin for prolonged or permanent residence.

The question of the right of expatriation was considered by the American Institute of International Law, and Article 3 of the draft convention approved by that body in its meeting in December, 1924, provided as follows:

"Naturalization can be granted in an American Republic only

${ }^{3}$ Act of Sept. 22, 1922 (42 Stat. at L. 1021). 
when the foreigner proves that by such naturalization he loses nationality in his native country."

It is quite remarkable that a body composed of representatives of the American Republics should have given its approval to the provision just quoted, which is directly opposed to the position taken by the Government of the United States many years ago and formally declared by the Congress of the United States in the famous Joint Resolution of July 27, 1868, in which it was asserted that "the right of expatriation is a natural and inherent right of all people, indispensable to the enjoyment of the rights of life, liberty, and the pursuit of happiness" and that "all naturalized citizens of the United States, while in foreign countries, are entitled to and shall receive from this Government the same protection of persons and property which is accorded to native-born citizens." 8

The provision quoted from the proposed Pan-American Convention is clearly reactionary, and it is not believed that the Government of the United States would ever give its assent to it. The same may be said of the provision of the Preliminary Draft of a Convention annexed to the report of the Sub-Committee of the League of Nations Committee of Experts for the Progressive Codification of International Law. It is found in Article 6, which reads as follows : ${ }^{10}$

"Naturalisation may not be conferred upon a foreigner without his having shown the will to be naturalised or at least without his being allowed to refuse naturalisation.

"Naturalisation acquired without the applicant being released from his allegiance by the State of origin does not give to the State according such naturalisation the right to give diplomatic protection to, and to intervene on behalf of, the person naturalised as against the State whose subject he originally was."

It is still more remarkable that.the International Law Associa. tion, a body composed principally of representatives of European countries, should have declared in favor of the right of expatriation. The Association adopted a resolution approving the declarations contained in the Joint Resolution of Congress of July 27, 1868 , and providing that, ${ }^{11}$

"the acquisition of a new nationality should ipso facto cancel any former nationality theretofore existing."

As to the liability of a naturalized citizen for an offense committed against his country of origin before his emigration there can hardly be any question, for the United States has recognized such liability in a number of naturalization treaties. ${ }^{12}$ In some

9 U. S. Rev. Sts., 1868, sec. 1999-2000.

10 Supra note 4, at 20.

11 Supra note 3, at 32 .

12 See for example Article 2 of the Naturalization Treaty of 1868 between 
of the naturalization treaties to which this country is a party it is specifically provided, however, that a naturalized citizen shall not be held liable to punishment for the act of enigration itself.13 Whether the provision last mentioned would be generally agreed to may be doubtful. Countries which lay stress upon the importance of keeping a hold upon their male nationals of the military service age might object to a provision such as that contained in the treaty with Sweden and Norway, and would probably insist upon a qualification to the effect that a person whose emigration involves desertion or failure to obey an express summons to appear for military service should be held liable to punishment upon his return.14 This problem of military service has so far prevented the conclusion of naturalization treaties between the United States and some of the principal countries of Europe. But for this impediment no doubt all countries would agree to the right of expatriation. It will be hard to overcome it until the principal powers of Europe have agreed to abolish large standing armies in times of peace. Even our owm country has qualified the declaration contained in the Joint Resolution of $1868 \mathrm{by}$ the provision of Section 2 of the Expatriation Act of MTarch 2, 1907,15 "that no American citizen shall be allowed to expatriate himself while this country is at war." This provision has accomplished no good whatsoever, and, as it has been construed, it has had a very absurd result. American nationals who took foreign oaths of allegiance while the United States was neutral in the World War, even in connection with entry into the armies of countries with which the United States later became associated in the War, are held to have lost their American nationality, while those who took foreign oaths of allegiance after the United States had entered the War, even in connection with entry into the enemy armies, did not thereby lose their American nationality. The provision in question should be repealed and replaced by a provision penalizing an act of expatriation committed by an American

the United States and Belgium, 1 Malloy, Treaties Conventions, cte., betwecrs the United States and Other Powers (1910) 80.

13 See, for example, Article 2 of the Naturalization Treaty of 1869 between the United States and Sweden and Norway, 2 IIalloy, op. cit. 1759.

14 The naturalization convention of 1870 between the United States and Austria-Hungary provided in Article II that a naturalized American citizen of Austrian or Hungarian origin should be liable to punishment in AustriaHungary under any of the following conditions:

"1st. If he has emigrated, after having been drafted at the time of conscription, and thus having become enrolled as a recruit for service in the standing army.

"2d. If he has emigrated whilst he stood in service under the flag, or had a leave of absence only for a limited time.

"3d. If, having a leave of absence for an unlimited time, or belonging to the reserve or to the militia, he has emigrated after having reeeived a call into service, or after a public proclamation requiring his appearance, or after war has broken out." 1 Malloy, op. cit. 45 .

1534 Stat. at L. 1228. 
national while this country is at war. It would seem sufficient to provide that such a person should thereafter be ineligible to naturalization in this country. Incidentally it may be added that the law should also be amended to make it clear that no American national can expatriate himself by taking a foreign oath of allegiance or obtaining foreign nationality while he is within the territory and jurisdiction of the United States. The country need not be greatly concerned over the cases of nationals who commit acts of expatriation in foreign countries while this country is at war. Retention of such persons as nationals is not desirable, and the present statutory presumption will never serve to prevent acts of disloyalty.

As to the status of naturalized citizens who resume their residence in their native lands, it may be observed that such cases were made the subject of a special Pan-American Convention, signed at Rio de Janeiro August 13, 1906, to which the United States is a party, and in which it is provided that a person of the class mentioned should "be considered as having reassumed his original citizenship, and as having renounced the citizenship acquired by the said naturalization." 18 There would seem to be no reason why a provision such as this should not be generally accepted. Controversies might arise in particular cases as to whether individuals have in fact established a residence of a permanent character in their native lands, but it is difficult to devise any international agreements concerning the administration of which controversies might not arise. It may be added that the provision in question is based upon the same principle which underlies the provisions of the second paragraph of Section 15 of the Naturalization Act of June 29, 1906,17 and the second paragraph of Section 2 of the Expatriation Act of March 2, 1907,18 both of which were discussed in the writer's article on Naturalization and Expatriation. ${ }^{10}$

It might be possible to obtain general international agreement to a provision reading somewhat as follows:

A national of a state has a right to expatriate himself, provided that, at the time of his emigration, he has not been summoned for active military or other service to the state. An expatriate, however, shall remain liable to punishment for any offense committed against his former state before emigration or for emigration after a summons of the kind mentioned has been made upon him and has not been obeyed.

If a person who has acquired the nationality of a state through naturalization returns to the state of his former allegiance for permanent residence, he shall be deemed to have renounced his naturalization and to have resumed his former nationality.

103 Malloy, op. cit. 2882.

17 34 Stat. at I. 596, 601.

18 Supra note 15.

19 Supra note 1. 


\section{THE PROBLEM OF DUAL NATIONALITY}

Dual nationality arises in multitudes of cases of persons born in one country of parents who are nationals of another. Discussions of this problem always involve the question whether the various countries of the world may be induced to adopt a uniform rule for native citizenship, or, if not, whether a general agreement upon a rule for terminating the condition of dual nationality after the persons concerned reach the age of majority, or even before, may be adopted.

The present writer suggested in his article on Dua? Nationality and Election, ${ }^{20}$ that dual nationality might be prevented by a general agreement to a rule that nationality should be dependent upon the parental domicile at the time of the child's birth. It was pointed out, however, that this would involve an amendment of the provision of Article 14 of the Amendments to the Constitution of the United States and amendments of provisions round in the Constitutions of certain Latin American countries. Another practical objection to this proposed rule is the difficulty which would be encountered in many cases in proving the place of the parental domicile at the time when an individual was born.

The American Institute of International Law attempted to solve this problem by Article 1 of the proposed Pan-American Convention which reads as follows:

"Individuals born on the territory of an American Republic are nationals of the said republic, whatever may be the nationality of their parents; such individuals, on reaching majority may make a declaration expressing a desire to the contrary and adopt the nationality of the country of their father or mother."

The International Lav Association attempted to solve this same problem by the following provision contained in its proposed "Model Statute:" $=x$

"(a) Every child born within the territory of a conforming State shall become a national of that State. Provided always that in any case in which the father . . of such child, being a national of another State, shall within a specified preseribed period register such child as a national of the State to which he belongs, such child shall cease to be a national of such conforming State and shall become a national of the State to which its father - $i$ belongs.

“(b) Every child born within a conforming State which has, pursuant to the proviso contained in sub-section (a), become the national of its father's . . . State, who shall within a year after attaining the age of twenty-one years claim to be re-admitted as a national of such conforming State, shall be so re-admitted without having to comply with any other conditions."

It is believed that neither of the proposed provisions just quoted

20 Supra note 1.

21 Supra note 3, at 29. 
would conflict with the provision of Article 14 of the Amendments to the Constitution of the United States. The declaration therein that "all persons born . . . in the United States, and subject to the jurisdiction thereof, are citizens of the United States and of the State wherein they reside" does not, it is believed, prevent the enactment of a law or the conclusion of a treaty providing for the termination of the American nationality of persons born in this country. It is believed that the Constitutional provision quoted was intended merely to make it clear that all persons born in the United States and subject to its jurisdiction, without regard to race, are born citizens of this country. In other words, it is a rule for determining acquisition of citizenship and not a rule for determining loss of citizenship.

The objection to the provisions recommended by the American Institute of International Law and the International Law Association is that both of them make it possible for persons born in a country to divest themselves of the nationality thereof while remaining resident therein. From the point of view of the United States and other countries having a large alien population, such a provision could hardly be found acceptable. There would seem to be no objection to the provisions of the Institute and the Association, however, if they should be modified by the addition of clauses to the effect that the election of the nationality of the parents in the case of a native citizen could be made only after such native citizen had ceased to reside in the country of birth.

The International Law Association recommended an international convention to apply to cases where dual nationality exists. It reads as follows :22

“( 1 ) Where any person is a national of two contracting Powers by reason of a conflict between their respective laws such person shall, while resident within the territory of either Power, be treated as exclusively under allegiance to the Power within whose territory such person is resident, and shall, while such residence continues, cease to be subject to any duties or liabilities affecting the nationals of the other Power as such nationals.

"(2) Where any person is a national of two contracting Powers as aforesaid, such person shall, while residing within the territory of any third Power, be treated as exclusively under the allegiance of the contracting Power whose protection has been claimed by application for a passport, certificate of origin, or other document identifying the national status of such person."

The first paragraph of the proposed convention just quoted is unobjectionable. To all intents and purposes it is a declaration of a generally recognized rule of law..$^{23}$

The second paragraph of the proposed convention would probably, for all practical purposes, be satisfactory in operation. It may be observed, however, that the problem of dual nationality

22 Supra note 3 , at 31.

${ }_{23}$ Flournoy, Dual Nationality and Election, supra note 1, at 703-704. 
does not often raise difficulties except where the person concerned is within the jurisdiction of one or the other of the countries claiming his allegiance.

The League of Nations Sub-committee seems to hare despaired of devising any workable and generally acceptable rule for either preventing or terminating the condition of double nationality. The opinion is expressed that" "it is doubtiul whether uniform rules for the solution of conflicts could be established without encountering political obstacles making the introduction of international instead of national rules impossible." The report concludes" ${ }^{25}$ "that any proposal put forward with the object of avoiding conflicts of law must end in the drawing up of a uniform law on nationality. The tendencies governing international practice at the present time, however, would make such a solution impossible." In the "Preliminary Draft of a Convention" annexed to the report the only provisions touching dual nationality are found in Articles 1 and 5 which read as follows :-20

"Article 1. The High Contracting Parties undertake not to afford diplomatic protection to and not to intervene on behalf of their nationals if the latter are simultaneously considered as its nationals from the moment of their birth by the law of the State on which the claim would be made."

"Article 5. A person possessing two nationalities may be regarded as its national by each of the States whose nationslity he has. In relation to third States, his nationality is to be determined by the law in force at his place of domicile if he is domiciled in one of his two countries.

"If he is not domiciled in either of his two countries, his nationality is determined in accordance with the law in force in that one of these two States in which he was last domiciled."

It is obvious that these proposed provisions would furnish no solution of the problem. It can not be solved without radical amendments of the nationality laws of the various countries concerned.

If it should be found impossible to adopt a rule to prevent dual nationality from arising, it is believed by the writer that it might still be possible to agree upon a rule for terminating this unfortunate condition. The writer can think of no better solution than that which was suggested in his previous article on this subject published in the YALE LAW JOURNAL to the effect that the domicile of the person concerned at the time of reaching the age when he is capable of making an election should determine his nationality thereafter. It might be desirable to allow such person a period of one year after reaching the age of majority to settle the question. The following rule is therefore suggested, for inclusion in a model statute or an international convention:

\footnotetext{
24 Supra note 4 , at 6.

25 Supra note 4 , at 6.

26 Supra note 4, at 20.
} 
"A person who is born a national of one country under jus soli and a national of another country under jus sanguinis, if he is domiciled in either of the two countries when he reaches the age of 22 years shall thereafter be regarded as having lost the nationality of the other. If, at the time when he reaches the age of 22 years, he is domiciled in a third country, he shall thereafter be regarded as having the nationality of that one of the two countries claiming his nationality in which he was last domiciled."

The advantages of this proposed rule are first, its simplicity, second, the fact that the nationality of the person concerned is determined by his own acts and not by mere declarations, and third, that it observes the rule that nationality and domicile should, whenever possible, coincide.

It will doubtless be objected that the proposed rule would work a hardship in some cases, but it should be realized that no effective rule for terminating dual nationality can be devised which will not cause inconvenience to some of the individuals affected. It should be borne in mind that the effect of the proposed rule is not to deprive the individual of nationality altogether, but merely to determine which of two nationalities he is to retain. Furthermore, if such a person has an earnest desire to be a national of the country in which he is not domiciled upon attaining the age mentioned, it may still be possible for him to take up his residence in such country and acquire naturalization therein.

It might further be objected that the proposed rule would violate the provision of Article $\mathrm{V}$ of the Constitution of the United States that no person "shall be deprived of life, liberty or property without due process of law." This same objection was advanced in the case of Mackenzie v. Hare, ${ }^{27}$ against Section 3 of the Expatriation Act of March 2, 1907, in which it was provided that ${ }^{29}$ "any American woman who marries a foreigner shall take the nationality of her husband," that is, shall lose her American nationality. But the Supreme Court held that the argument was invalid, since any American woman who married an alien after the passage of the statute in question must be deemed to have done so "with notice of the consequences" of her action, under the statute. The same would be true of a person born in the United States of alien parents who should retain a domicile in the country of his parents' nationality until reaching the age mentioned. It would be only reasonable in such a case to impute to the person in question a deliberate choice of the nationality of his parents and renunciation of the American nationality acquired by the accident of birth in this country. It may be added that little, if any, real hardship would be involved in the application of the proposed rule. In nearly all cases it would be found that the persons affected had been domiciled in their parents' country since early childhood.

\footnotetext{
27 (1915) 239 U. S. 299, 36 Sup. Ct. 106.
}

28 Supra note 15. 
THE PROBLEM OF NO NATIONALITY

This would not be mentioned as one of the major problems concerning nationality were it not for two facts; first, that writers on international law and the law of nationality usually assume that the existence of persons having no nationality is more or less of a calamity, for which a remedy should be sought, and second, that cases of no nationality have been increased by the passage of the Cable Act ${ }^{29}$ concerning the nationality of married women.:9 The cases last referred to are those of foreign women who have married American citizens since September 22, 1922 and, under the laws of their countries, have lost the nationality thereof, but, under the provision of Section 2 of the Cable Act, have not acquired American nationality. The condition of no nationality also exists in the cases of Americans who have lost their American nationality, under the provision of Section 2 of the Act of March 2, 1907,31 by taking foreign oaths of allegiance. Again, this condition may exist in cases of naturalized citizens who, having resided for two years in their native lands or five years in other foreign countries, have brought upon themselves the presumption of expatriation under the same statute. Unless and until such presumption has been overcome, such persons are in the position of having no nationality. If it is really a matter of great importance to prevent the condition of no nationality from arising or to make it easy for the individual concerned or his parents to terminate it, special rules to cover these cases could no doubt be devised without much difficulty. Thus, it might very well be agreed that the administration of an oath of allegiance to an alien shall always be regarded as equivalent to naturalization. Cases of naturalized citizens who have resumed residence of a permanent character in their native lands would be covered by a provision similar to that contained in the Pan-American Convention of 1906, mentioned above. Perhaps a general rule for the naturalization of a person having no nationality after a comparatively brief period of residence might be agreed to. With regard to this question it may be observed that the resolution of the International Law Association mentioned above contains a provision that ${ }^{32}$

"nationality should only be lost after the effect of the acquisition of another nationality."

The provision just quoted is not deemed desirable. It would nullify the provision of Section 2 of the Expatriation Act of MIareh 2, 1907, concerning the presumption of expatriation arising

\footnotetext{
so Supra note 8.

20 See Flournoy, New Marricd Tomen's Citizensitin Lun", ossuce note 1.

$\approx$ Supra note 15.

so Supra note 3 , at 32.
} 
against naturalized citizens because of protracted residence abroad, and would make it impossible for any country to provide by domestic legislation for the expatriation of its nationals except in cases where they acquire another nationality.

While there seems to be no reason for making special provisions to prevent persons from divesting themselves of nationality by their own deliberate acts, it may be desirable to attempt to adopt measures to clothe all persons with the nationality of some country at birth. For this purpose the following provisions of Articles 3 and 4 of the League of Nations draft convention would seem adequate : $:^{33}$

"A child born of parents who are unknown or whose nationality cannot be ascertained acquires the nationality of the State in which it was born or found when it cannot claim another nationality in right of birth, proof of such other nationality being admissible under the law in force at the place where it was found or born."

"Article 4. A child born outside the State of which its parents are nationals has the nationality of the State where it was born if the State of origin does not give the parent's nationality to such child."

It may be observed, however, that Article 4 would not be acceptable to countries, such as our own, whose laws of native citizenship are based primarily on jus soli, if it means that a child is not to be regarded as a citizen of the country of birth in any case where it is claimed as a national of another country of which its parents are nationals.

\section{THE PROBLEM OF THE NATIONALITY OF WOMEN WHO MARRY MEN} HAVING A NATIONALITY DIFFERENT FROM THEIRS

It need hardly be said that this problem has arisen in most cases from the passage of the Cable Act and the subsequent agitation carried on in other countries for the passage of similar legislation, under which a woman does not acquire the nationality of her husband by the fact of her marriage to him and is not naturalized as a citizen of another country through his naturalization therein. The International Law Association included in its "Model Statute" a section reading as follows : ${ }^{34}$

"(a) A woman national of a conforming State shall not by reason of her marriage with a national of a non-conforming State lose her original nationality, unless or until by reason of such marriage she becomes a national of such other State, either automatically or by naturalization.

"(b) A woman national of a conforming State marrying a national of another conforming State shall acquire her husband's nationality, unless she does, under the law of the State to which she belonged before marriage, retain the nationality of such State,

${ }^{33}$ Supra note 4, at 20.

84 Supra note 3 , at 30. 
or unless she makes a formal declaration (to be recorded on the register of marriages) to the effect that she wishes to retain her former nationality."

To meet the troublesome cases arising out of provisions of nationality laws such as the Cable Act the League of Nations Subcommittee makes the following proposals, contained in Articles 9 and 10 of the draft convention: : $^{35}$

"Article 9. A married woman loses her original nationality in virtue of marriage only if at the moment of marriage she is regarded by the law of the State to which her husband belongs as having acquired the latter's nationality.

"Where a change in the husband's nationality occurs during the marriage the wife loses her husband's nationality only if the law of the State whose subject her husband has become regards her as having acquired the latter's nationality."

"Article 10. A woman who does not acquire through marriage the nationality of her husband and who, at the same time, is regarded by the law of her country of origin as having lost her nationality through marriage, shall nevertheless be entitled to a passport from the State of which her husband is a national on the same footing as her husband."

It is believed, notwithstanding the arguments put forth by those who favor the rules contained in the Cable Act, that the maintenance, so far as possible, of the unity of the family as to nationality is most desirable. Moreover, it is believed that most women are content to take the nationality of their husbands, unless, perhaps, they continue to reside after marriage in their own countries. If it is possible to obtain an amendment of the Cable Law, it is believed that a rule providing somewhat as follows might be generally agreed to:

"A woman who marries a man having a nationality different from hers or whose husband acquires a nationality different from hers through naturalization shall take the nationality of her husband unless, within a period of one month before or aiter the marriage or the naturalization of the husband, she malies a formal declaration of a desire to retain her own nationality. However, if such a woman acquires a domicile in the country of which her husband is a national, she shall ipso facto acquire his nationality."

It is believed that a rule such as that just quoted would contain a sufficient concession to women who desire to assert their own rights as to nationality.

It is interesting to observe that Miss Chrystal MIacilillan in the discussion at Stockholm, contended that the mother of a child as well as the father should have a right to decide the nationality of the child in a case of dual nationality. She did not explain which choice would prevail in case they differed, but her opinion upon this point may be surmised. In the same discussion Dr. G. iI. Palliccia made the following observations. ${ }^{28}$

\footnotetext{
35 Supra note 4 , at 20.
}

so Supra note 3, at 43 . 
"According to my opinion you have to choose either the nationality of the husband or the nationality of the wife. I do not say that the husband is a higher or more perfect animal than the wife. I think perhaps very often ladies are more perfect than gentlemen; but as one must be the head of the company or of the State, so we must have a head in a family. Either it must be the husband or it must be the wife.

"Let us have one nationality, and, if you like, let us choose the nationality of the wife, instead of that of the man. There will be perhaps a certain return to the period of matriarchy, but, after all, the world was not so bad under matriarchy."

\section{CONCLUSION}

The report of the Sub-committee of the League of Nations does not give much encouragement to those who have hoped that conflicts of nationality laws might be removed by international agreements. The committee approached the subject in a very cautious and conservative spirit, with evident reluctance to the making of proposals which might seem to be chimerical or to question in any degree the moral and legal right of States to have nationality laws adjusted in every particular to their own political needs as they see them. The rapporteur, M. Rundstein, made the following rather pessimistic observations :

"It is obvious that, when a problem has a political as well as a legal aspect and the former must prevail over the latter, no action can be taken. It is therefore impossible to effect a uniform regulation of all problems arising out of conflicts of nationality; the work can only be achieved by a process of selection and elimination. No solution can be hoped for where there is the slightest suspicion that the problem is of a political nature."

"Two very eminent jurists, Weiss (Treatise I, page 329) and Oppenheim (International Law, I, page 487), have hoped that the solution of the conflicts with which we are dealing might be obtained by establishing a uniform law embodied in an international convention, or by formulating an international obligation for the States to revise their internal laws on a common basis, which would serve as a model for the drafting of such laws. This would represent an ideal, the maximum which any international jurist would have the right to contemplate.

"I am of opinion, however, that, in order to reach this goalwhich would mean the solution of all conflicts-it will be necessary to proceed by stages, for a universal regulation touching upon the substance of the matter would not seem to be compatible with the legal situation at the present day; it would surely be unfortunate if, by attempting tasks which for the moment are beyond us, we were to fail to achieve results which, although modest, would be of great value and, last but not least, practicable." $3 s$

While no one who has given this subject careful thought can entertain a reasonable hope that the present conflicts can be removed in the immediate future by the waving of a magic wand

37 Supra note 4 , at 20.

${ }^{38}$ Supra note 4, at 13. 
in the shape of an international code, the writer believes that much may be accomplished through persistent and intelligent effort and a spirit of reasonable conciliation, although it must be realized that the obstacles will be hard to overcome so long as militarism continues to exist and large standing armies continue to be maintained. The chief difficulties arise from the need, actual or supposed, of certain countries to retain the allegiance of all men upon whom they have any claim for their armies. However, the success of the government of our own country in concluding the naturalization conventions of 1868-1871 with the German states and Austria-Hungary, and in persuading Great Britain not only to enter into the convention of 1870 but even to amend her nationality law and abandon the antiquated principle of indissoluble allegiance, should encourage the belief that the existing conflicts in nationality laws, or most of them, may yet be removed. If it is possible to accomplish a general reduction of armaments through international agreements, it is surely within the range of possibility to remove conflicts of nationality laws in the same way. If anything of real value is to be accomplished, however, it will be necessary to approach the subject in a temper more aggressive and more constructive than that exhibited by the League of $\mathrm{Na}$ tions Committee. INere statements of the few points as to which general agreement now exists and attempts to remove minor conflicts should not be accepted as sufficient. An effort should be made to settle the major problems, particularly the question of the right of expatriation and the question of the prevention or termination of dual nationality arising out of conflicting claims based upon jus soli and jus sanguinis. The best procedure for accomplishing the desired result would probably be the formulation by experts from the interested countries of a code covering all conflicts of importance and the conclusion of a multilateral convention, not adopting the code, but merely agreeing to recommend it, as a whole or in part, to the legislative bodies of the signatory powers for their consideration and possible adoption. 